\title{
BOOK REVIEW - JOHN DEWEY AND THE FUTURE OF COMMUNITY COLLEGE EDUCATION
}

Review by Stan Skrabut, PhD, Director for Technology Enhanced Instruction, Jamestown Community College

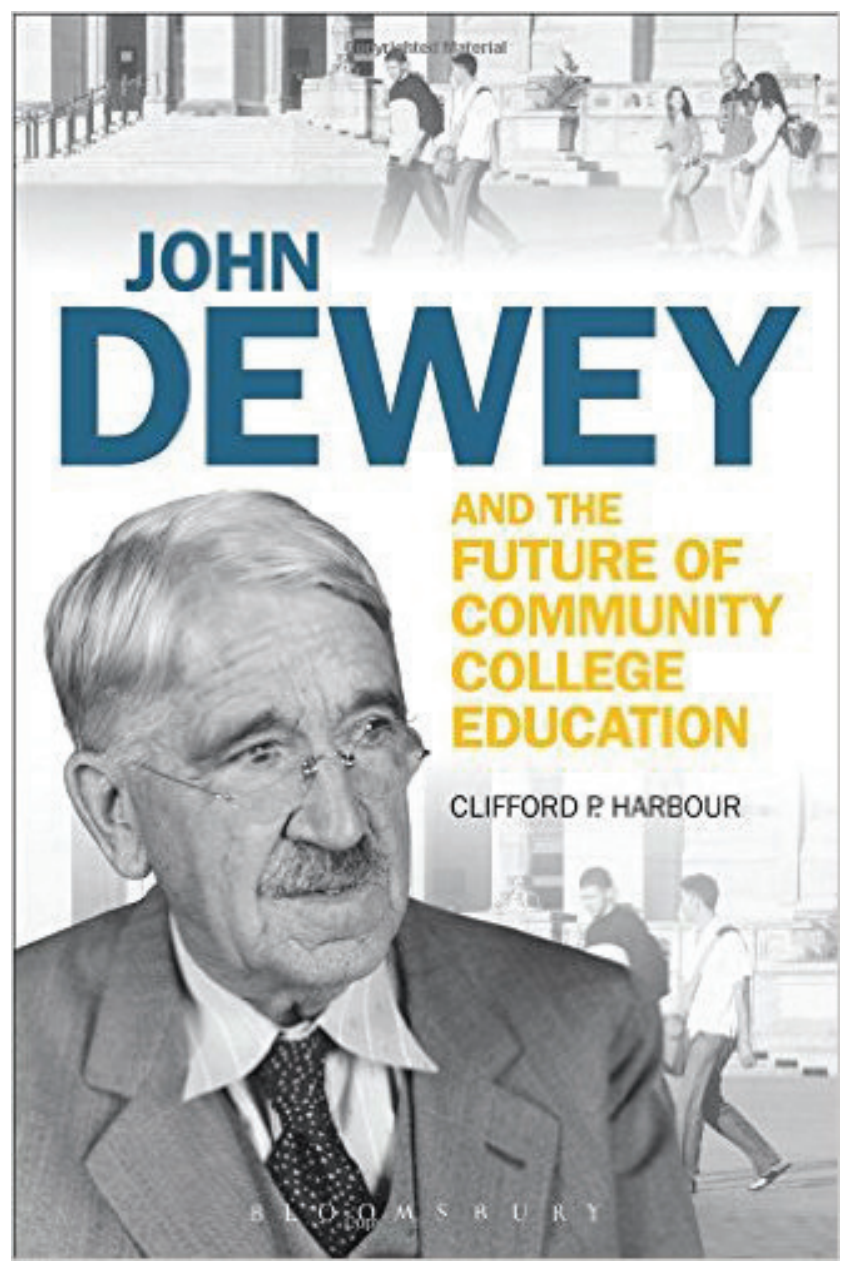

John Dewey and the Future of Community College Education

by Clifford P. Harbour

Bloomsbury Academic, 2014, 192 pp.

ISBN 13: 978-1441172921 \$29.95
In his book, John Dewey and the Future of Community College Education, Clifford Harbour has shown community colleges to be quite adept at taking on increased responsibilities by adapting to their communities' changing needs throughout the decades. His concern lies with the increased external completion pressures and their effect on community colleges. While Harbour believes community colleges should improve graduation rates, he also believes community colleges should be more than institutions to impart knowledge and skills but also shape democracy in local communities. To help support his position, he reflects on John Dewey's teachings.

When Harbour wrote this book, community colleges were not only tasked with increasing access to education but now required to increase completion rate with successful job transition. During the beginning of the 20th century, the United States suffered from wage inequalities, unemployment, unprecedented technology changes, high immigration rates, increased poverty, and war issues that continue to hold the United States back. Then and now, legislators promote education as means to prosperity and equality. Yet, the world's economy has increasingly become complex. To compete in this new economy, the nation needs a more educated workforce. President Obama advocates for community colleges to produce 5 million new graduates (The White House, n.d.). "Policymakers, legislators, and private foundations are calling upon community colleges to retain their commitment to access while also significantly improving their graduation rates" (Harbour, 2014, p.vi). To help community colleges create a framework to navigate this new mission, Harbour's purpose is threefold:

- explain how community colleges developed over the 
decades as a means to provide education opportunities for all.

- reflect upon the writings of John Dewey as they relate to the expansion of education opportunity to all and the impact to communities.

- "identify and explain the values and priorities that would comprise a Deweyan normative vision for the community college of the future" (Harbour, 2014, p.8).

John Dewey and the Future of Community College Education has eleven chapters spread across three sections. To provide context in part one, Harbour looks at the contemporary community college, the community college of the future, and introduces John Dewey. Part two focuses on the community college evolution by first looking at the beginning of the junior college, how junior colleges evolved during the Great Depression, and how community colleges developed in the late twentieth century. Part three explores John Dewey's writings on education, democracy, and community. Finally, Harbour explores the Deweyan community college, a possible framework for moving community colleges forward under this new mandate.

Throughout the book, Harbour ties his writing back to essential documents and events shaping junior and community college development to include John Dewey's documents. He points out key historical events such as the two world wars, the Great Depression, and the Great Recession and their impact upon the community college system. As he notes, this book is not an exhaustive account of documents and events related to the community college movement. He focuses only on elements necessary to develop his Deweyan normative vision framework.

\section{Part One - The Context}

In part one (chapters 1-3), Harbour focuses on three topics: the contemporary community college, the community college of the future, and an introduction to John Dewey. In this section, he provides an important glimpse into the community colleges' mindset through a quick community college system overview. While looking at contemporary community colleges, he examines governance, organizational leadership, and structure; faculty education, composition, and teaching loads; student population; curriculum; core missions; funding; and the Completion Agenda. A student population examination shows rising but stable growth with a higher proportion of minority and low income students as compared to universities. He outlines the community college's core mission as one providing open access to a comprehensive curriculum and serving a local community's needs. The curriculum may deliver associate degrees, vocational certificate programs, or non-credit programs. He explains community college funding sources and variables affecting funding such as less tax revenue, incarceration costs, and Medicaid costs. Expenditure increases and income decreases have yielded less funds available for community colleges. This naturally affects affordable open access. With an increased emphasis on completion due to the Completion Agenda, there may be unintended consequences, e.g., encouragement to complete certificate programs and vocational programs rather than degree programs just to report success. Harbour draws attention to the difficulty of measuring completion when students are practicing "swirling" and "double-dipping" by taking courses from more than one institution. He argues community college education should promote more than access and completion but also democratic growth.

An examination of contemporary community colleges helps focus a lens on the future. Harbour identifies five areas influencing future community college development. "These are (a) income inequality, (b) technological change and learning analytics, (c) globalization, (d) the generational equity problem, and (e) public higher education funding" (Harbour, 2014, p. 32). The income inequality gap, the greatest since the Great Depression, disrupts governance at every level and threatens our nation's democracy (Harbour, 2014). It is imperative individuals continue to learn and advance their education as a means to close the income inequality gap and develop as educated voters. Community colleges can help learners by improving instruction. Harbour points out we still teach the same way we did 100 years ago in spite of technological advances.

Educators should use learning analytics to help students learn and complete degree programs. Generational inequity also affects community colleges; for example, different elderly programs exhaust funds younger citizens need to succeed. As a result, money must come out of the student's pocket; this is during a period when wages have remained stagnant. While community colleges continue to be prudent community investments by providing high 
quality education at a reasonable price, more can be done to control costs.

This section closes with an introduction into John Dewey. Harbour provides detail into the events that shaped Dewey's character and educational philosophy. Dewey saw labor issues, war, poverty, income inequality, civil rights, and suffrage issues. These events helped him realize education is not just for the privileged; society should not use education to support a class separation system. Dewey believed "the purpose of an education was to promote individual growth, to become a better person, and to acquire the skills and knowledge needed to work with others in building a better society" (Harbour, 2014, p. 54).

\section{Part Two - The Evolution of the Community College}

The second section (chapters 4-7) of Harbour's book explores community college development from the junior college movement. This section's first chapter focuses on junior college movement beginnings. According to Harbour, junior colleges were a connection between public high schools and universities. They helped strengthen a high school's curriculum as well as served as a release valve for universities, which could not easily accept more students, especially students who were not adequately prepared for university rigor. In this section, he uses specific junior college examples, various laws, and key documents written by Floyd McDowell, George Zooks, Leonard Koos, and Walter Eells to illustrate key advancements

The Great Depression had a significant impact on junior colleges. During the Great Depression, funding for education was in short supply and communities closed higher education institutions to save money. However, junior colleges, a cheaper alternative to universities, saw an enrollment increase. Additionally, the federal government used junior colleges as means to advance economic policy under the Emergency Education Program. "What the Great Depression revealed was that the nation had a genuine need for low-cost postsecondary education and many adult learners were grateful for the opportunity to take college classes at the junior college" (Harbour, 2014, p. 54). Harbour stresses the importance the federal government had addressing the economic crisis, a crisis the states were unable to address on their own.

As Harbour addresses the period from 1940 until 1970 , different events and documents had a role in shap- ing the junior college landscape. These events and laws included World War II, the GI Bill, the Truman Commission Report, the Donahue Act, and the California Master Plan for Higher Education of 1960. Across these events, junior colleges adjusted to training citizens and soldiers for war, and postwar reintroduced servicemen back into the civilian workforce thus expanding the new community college program. The Truman Commission Report, the Donahue Act, and the 1960 Master Plan created the community college system, delineated the roles of each higher education institution type, and decided the distribution of degrees. Community colleges also assumed a greater role of filtering out students who did not meet university standards.

In the last chapter of this section, Harbour focuses on important documents that are changing the direction of community college education: 1988 American Association of Community Colleges (AACC) policy document, Building Communities: A Vision for a New Century and 2012 AACC report, Reclaiming the American Dream. In the first document, authors believed community colleges could stem economic degradation and social polarization. The recent document's authors believed the United States no longer leads the world in degree completion and lack of completion contributes to income inequality. The report recommended changes to community college funding, operations, and structure.

\section{Part Three - Dewey on Education, Democracy, and Community}

The last section (chapters 8-11) focuses on John Dewey. The first three chapters look at John Dewey's writings and presentations in a historical context. The last chapter creates a normative vision framework for advancing community college education based on Dewey's teaching.

"We can learn from John Dewey, an American who thought carefully about the relationship between education and democracy during an era that in many respects is similar to our own" (Harbour, 2014, p. 117). Harbour uses Dewey's book, Democracy and Education, to highlight the importance education has had in building a better society. Dewey believed knowledge sharing about diverse people helps create greater understanding and reduces conflict. Because society keeps evolving, individuals need lifelong learning to make the society better. Community colleges are well suited to handle lifelong learning. 
Dewey recognized Americans would cling to the status quo unless they were responding to a crisis. Seeing social injustices all around him, he regularly wrote about them and how education could help mitigate them. Harbour used Dewey's book, Human Nature and Conduct, the debate with Walter Lippmann, and the Great Community to illustrate how educated citizens could solve world problems through collaboration and communication. For a Great Community to work, members would have to communicate with others, create community symbols, have ability to inquire, understand how to leverage social sciences for better policy, and disseminate results to all community members.

Harbour explains Dewey increased his leadership role through more writing and presentations as the Great Depression unfolded. Dewey often wrote about injustices and how schools failed to prepare citizens who could think about community issues. He spoke against a subject-centered curriculum that did not address real issues, and did not require critical thinking. "Simply relying on political institutions to solve the great problems was no longer a feasible strategy to advance American democracy" (Harbour, 2014, p. 151).

\section{Framework for a Deweyan Normative Vision}

The book concludes with a list of priorities and values for a Deweyan normative vision for community colleges. These eleven priorities and values center on grounding instruction, guiding democratic campus community development, and guiding the institution's relationship with the community. Of these eleven priorities and values, some resonated with me more than others. For example, Harbour explains educators must prepare learners to live and support their communities; this means educators must not teach sterile disciplines but provide a context for the topic within the community at large. Dewey and Harbour also stressed the need for learners to understand an occupation both historically and within society to adapt to changes in the future. Community colleges need to end the practice of tracking students and instead prepare learners for an occupation. Finally, community colleges should not only prepare learners for a democratic society but also model the process through transparent and open problem-solving within the institution. As Harbour concludes, community colleges need to recognize their past and leverage Dewey's teachings to assert themselves in shaping their future. This priorities and values framework can help community colleges shape their role as one for making their society better.

The limitation of this book would have to be the last chapter outlining a list of priorities and values for a Deweyan normative vision for community colleges. While I believe the list is accurate and beneficial, Harbour did not provide leaders with a clear blueprint on how to implement the framework. He noted each community college could use all, some, or none of the framework. It was up to each community college to implement the framework to suit their needs. I believe the book could have been made stronger with a more prescriptive approach to the framework. Harbour could have include more specific examples how to implement what he believes is necessary for the future of the community college system.

The book's greatest strength is how the author drew parallels from the period of Dewey's life to what is happening in the United States today. In the news, we hear about income inequality, poverty, unskilled labor, unemployment, war, etc. Community colleges were born in similar times and contributed to American greatness. The nation, states, and local communities are calling upon community colleges once again to aid a troubled nation. Harbour and Dewey advocate that an education is more than just developing knowledge and skills, it is also to benefit society.

This book is also a useful primer for understanding how community colleges differ from universities, colleges, and private liberal arts colleges. While I have served at a private liberal arts college and a land grant university, I am new to community colleges. I realized each institution has different missions, faculty, and curriculum; this book helped me gain a real understanding of the differences. Even though Harbour has not provided a detailed blueprint, an examination of the framework will serve college leaders well. Additionally, community college leaders will be able to see how recent changes to the core mission will impact their institutions. Harbour offers cautions throughout the book on how recent policy changes to meet completion mandates could alter the curriculum as institutions try to meet these mandates. Community college leaders need to take the completion mandates as a call to action to improve instruction, improve student support, and improve connection to community. While a detailed blueprint still needs to be developed, Harbour's book pro- 
vides college leaders and faculty with a framework that they could use to improve their institutions for educating students for a better society.

\section{Further Reading}

Harbour, C. P. (2014). John Dewey and the future of community college education. London; New York: Bloomsbury Academic.

The White House. (n.d.). Building American skills through community colleges. Retrieved from https://www. whitehouse.gov/issues/education/higher-education/ building-american-skills-through-community-colleges

\section{About the Author}

STANLEY A. SKRABUT recently earned his doctorate in education through the College of Education, University of Wyoming. He has worked as a trainer and instructional technologist for more than 25 years in the United States Air Force, Hobart and William Smith Colleges, the University of Wyoming, and Jamestown Community College. 